\section{Capitalism and inequality}

Recebido: 30.07 .20

Aprovado: 22.09 .20

Boike Rehbein*

Abstract: According to the prevailing opinion, capitalism is a market economy governed by immutable laws and inequality is the result of competition between free and equal individuals on that market. This paper argues that capitalism, as developed in Western Europe in modern times, has more in common with organized crime than with a system of natural laws. It is rooted in the sale of church and common lands, the privatization of finance (especially public debt) and colonialism. However, its purpose is not the accumulation of wealth. It is merely a particular way of sustaining domination by a small group of people over the rest of the population. Domination in capitalism differs from earlier forms of domination in two ways: it is reproduced via the accumulation of wealth and it is not visible as such. Neither the purpose (domination) nor the functioning (systematic appropriation) is visible on the surface. Even Marx was led to believe that the economy is governed by laws which can be studied scientifically. The paper will argue against this belief by tracing the structures of domination to the reproduction of social inequality in capitalist societies.

Keywords: Capitalism. Domination. Economic inequality. Social class. Social inequality.

\section{Capitalismo e desigualdade}

Resumo: De acordo com a opinião predominante, o capitalismo é uma economia de mercado regida por leis imutáveis e a desigualdade é o resultado da competição entre indivíduos livres e iguais nesse mercado. Este artigo argumenta que o capitalismo, conforme desenvolvido na Europa Ocidental nos tempos modernos, tem mais em comum com o crime organizado do que com um sistema de leis naturais. Está enraizado na venda de igrejas e terras comunitárias, na privatização das finanças (especialmente da dívida pública) e no colonialismo. No entanto, seu objetivo não éo acúmulo de riqueza. Esta é apenas uma forma particular de sustentar a dominação de um pequeno grupo de pessoas sobre o resto da população. A dominação no capitalismo difere das formas anteriores de dominação de duas maneiras: é reproduzida por meio da acumulação de riqueza e não é visível como tal. Nem a finalidade (dominação) nem o funcionamento (apropriação sistemática) são visiveis na superfície. Até Marx foi levado a acreditar que a economia é governada por leis que podem ser estudadas cientificamente. $O$ artigo argumentará contra essa crença ao traçar as estruturas de dominação até a reprodução da desigualdade social nas sociedades capitalistas.

Palavras-chave: Capitalismo. Dominação. Desigualdade econômica. Classe social. Desigualdade social. 


\section{Introduction}

E

very year, a new world-historical record in socio-economic inequality is proclaimed. In 2018, the 26 richest men owned as much wealth as the poorer half of the world population (almost four billion people) combined (The Guardian, 20 January 2019). Everybody knows this level of inequality is unsustainable, every capitalist state is worried about it, and a lot of measures are taken against it - but it keeps getting worse (Stiglitz, 2012: 20-25). This is partly because we understand neither capitalism nor inequality. And we do not understand them partly because we believe in the ideology that has been created around capitalism since the development of its modern, Western form (cf. Boltanski \& Chiapello, 1999).

According to this ideology, capitalism developed in Europe until it became so efficient that it spread across the world. This is not true. European capitalism developed in conjunction with colonialism and spread across the world due to colonialism. According to ideology, capitalism is a market economy that is governed by natural laws. This is not true. Capitalism is almost the opposite of a market, it is the monopolization of capital in the hands of few, which has nothing to do with natural laws. According to ideology, the core of capitalism consists in the utilization of wage labor. This is not true. Wage labor played a key role only during industrialization, otherwise capitalism seeks to exploit anything and everything. According to ideology, the division of productive labor is the driving force of capitalism and the domination of finance is an aberration. This is untrue. Finance has been the motor of capitalism.

The ideological view of capitalism combines with the invisibility of structural domination to construct an entirely misguided understanding of inequality. According to the conventional view, capitalism created a complete break with the past: Suddenly, all individuals were free and equal. The core of capitalist society was supposed to be competition on a level playing field for wealth. It is difficult to construct a myth that is further from the truth. The precapitalist inequalities were not abolished by capitalism and not even by the advent of democracy. And competition in capitalist societies is not about money. It is about capital but only a tiny group monopolizes capital and actually competes for it. The rest competes for means of consumption. However, capital is only a means for domination. Inequality, in reality, is about domination. Since the structures of domination are rendered invisible in capitalist societies, very little can be done about inequality.

In this paper, I will elaborate briefly on each point listed in the two preceding paragraphs. I try to show that capitalism is tied to colonialism, has nothing to do with a market or natural laws, consists in the exploitation of anything and is driven by fi- 
nance capital. And I will argue that inequalities in capitalist societies are merely transformations of precapitalist hierarchies, are mediated by the monopolistic ownership of capital and are rooted in domination. A final section will deal with the hierarchy of social classes in capitalist nation states and their relation on a global scale.

\section{Definitions}

A meaningful definition of capitalism would have to distinguish between its different forms and to address at least some of the issues mentioned in the introduction. Therefore, it can only be the result of a study, not its beginning. However, I would like to start with a working definition to make my line of argument as transparent as possible. I think it is acceptable to begin with Max Weber's (1986: 12-14) definition of a "capitalist action" as an investment with the expectation of a profit. It is important to note that capital is an investment. There are other forms of wealth (such as money, real estate or a car) but they are not capital unless they are invested. And there are other forms of making a profit, such as begging or stealing, but they are not capitalist unless they flow from an investment of capital.

A capitalist is a human being that owns capital as a property before engaging in a capitalist action. Capital is not the result of capitalism but a precondition. And it cannot be common property; capital and profit are private property, from which other people are excluded. The individual capitalist invests in order to replace the original capital and to generate a surplus, which is the profit. The capital itself does not diminish, it is not spent but always replaced. The capitalist lives off the profit. Whoever spends his or her capital on consumption is not a capitalist. The ideal type of a capitalist action consists in acquiring something with a certain invested amount of capital and selling it at a higher price. This something can be someone's labor power but it could also be anything else.

With Weber, we have to understand capitalism as a contextual phenomenon. It does not have one universal shape but comes in various configurations depending on the historical circumstances. Weber (1986: 14) argued that capitalism has existed in many places and times. Particular about modern Western capitalism is that it penetrates all spheres of life, so that we can speak of a capitalist society and not just of a capitalist economy. Everywhere else, it has always been limited to a small group of traders or capitalists. Capitalists were a caste or rank or community, often of subordinate status. Today, capitalism penetrates all spheres of society and integrates more or less every member of society (Polanyi, 1944). This was the result of the development of European capitalism. Therefore, I will limit my argument to this type of capitalism, namely institutionalized Western capitalism. 
Inequality is usually studied in quantitative and economic terms. These generally refer to income and, less frequently, to profession or wealth. This approach is misleading. It reduces the issue of inequality to one dimension, which is not even the most relevant one. Inequality is about domination, not about money or careers. We are made believe that we compete for a better job or more money. The cards for this competition, however, are dealt before it even begins. And the competition mainly takes place within the peer-group or the framework of a social class. Ideology tells us that the best in this competition win and that wealth or success is due to individual merit. Thereby, it renders the conditions and structures of competition invisible.

This paper deals with social inequality, which is not only determined by the distribution of economic goods and professions but also by the distribution of other forms of resources and habitus (Bourdieu, 1984) as well as by the historical development of society. Social inequality signifies the differential access to activities, positions and goods that are valued in society - or the structure of privileges. In a later section, I will try to show that the distribution of resources is not so much a result of competition but a heritage that is reproduced from one generation to the next. In capitalist societies, this legacy is passed on within boundaries of social classes. I define social class as a tradition line which reproduces itself from one generation to the next by passing on relevant resources and habitus traits to the next generation as well as by symbolically distinguishing itself from other classes. This concept of social class can be operationalized by establishing the relative limits of social mobility. Social mobility takes place within the boundaries of a social class but rarely crosses them. A tradition line is a common class culture, which is based mainly on habitus (Thompson, 1963).

The hierarchy of social classes is rooted in and conditioned by precapitalist hierarchies. These partly persist for generations after the emergence of capitalism next to the social classes. I refer to these precapitalist hierarchies as sociocultures. The structure of inequality in any capitalist nation state can be explained as a transformation and persistence of sociocultures in combination with political interventions, crises and the position in the world system.

\section{Colonialism}

The first assumption we have to refute postulates that capitalism emerged within Europe due to its superior organization and productivity of the economy. Adam Smith and Karl Marx agree that science, technology, the division of labor and the free market were responsible for the success of capitalism in Europe before it spread across the world. These factors were important indeed - but only after 
capitalism had spread across the world. The steam engine, gun powder and metal factories with a thousand workers existed in China long before any European even dreamt of them (Jones, 1988: 15, 74).

Colonialism was the driving force of European capitalism before industry and technology began to matter. Colonialism was rooted in the crusades and played a crucial role in the expansion of the North Italian city states after 1000 CE. Venice was the main mediator of trade between Asia and Europe between 1204 and 1453, but it was also involved in the crusades and practiced colonialism by occupying territories in the Eastern Mediterranean, where slaves and indented laborers produced agricultural and manufactured goods for the Venetian population, especially the elites. In 1453, the Ottomans conquered Constantinople, which had been a Venetian colony since 1204. Europe no longer dominated the Eastern Mediterranean and the link to the Arab trade network was severed. Genova and Portugal explored alternative trade routes and in 1492, Columbus landed in America. Portugal and Spain began to dominate Europe's long-distance trade, which they financed with precious metals from America (Frank, 1998).

Other European states contested Spain's position and robbery was the main principle of European "trade" during that period. Spaniards robbed gold and silver in America, Spaniards, Portuguese and Dutch robbed goods along the Asian coast or traded the precious metals for them, Dutch robbed Spanish and Portuguese ships sailing back to Europe (Panikkar, 1955: 51-57). Increasingly, the English pirates were most successful and with the defeat of the Spanish military fleet, the Armada, in 1588, England became the dominant European trading power.

Piracy was supported by the English crown but more important for the development of capitalism was the foundation of colonial companies in Northwestern Europe. The colonial companies were shareholder societies, actual corporations, founded by nobility, monarchs, representatives of the state and traders. They received monopolies for particular world regions and were supported by the state (Bairoch, 1993: 89). Rich individuals contributed to funding expeditions by investing money with the expectation of significant returns - they acted as capitalists. The English crown sold shares of the colonial companies and thereby generated a profit. The shareholders made a profit when the expeditions were successful. Profits could be astronomical - in the seventeenth century, clove averaged a profit rate of 2500 per cent (Panikkar, 1955: 96).

This was the birth of modern capitalism. Capital was not accumulated via production but via piracy, robbery of raw materials, metals and goods, slavery and betrayal. 
This happened as an investment by capital owners, legitimized and supported by the state (Braudel, 1985: 60). While Venice focused on trade, Spain and England focused on exploitation. And whereas Spain practiced exploitation mainly for the sake of the monarch, England practiced exploitation for the sake of the capital owners (including the monarch). England was the main force in the development of capitalism - however, not through nineteenth century industrialization but through seventeenth century colonialism.

Colonialism resulted from the concerted action of the dominant ranks of feudal society, the rulers of the nascent nation state and capitalists. These groups merged to become the dominant class of capitalist society. In the course of this development, colonialism transformed into imperialism. The colonies were no longer exploited by private companies but administered by organs of European nation states, who, in 1914, ruled over 85 percent of the surface of the earth (Nederveen Pieterse, 1989: 179). Profits were increasingly used to develop European manufacturing into large-scale industries. Colonies were converted into plantations, suppliers of raw materials and markets for European manufactured goods (Osterhammel, 1995: 36). Industries that already existed in the colonies were destroyed and the development of new industries was prohibited (Nederveen Pieterse, 1989: 115). The most famous example for this is the praised Indian textile industry, which was thereby replaced by the nascent British textile industry (Bose \& Jalal, 1998: 56).

The most important consequence of colonialism was the creation of an integrated unequal world order. In the process, up to 262 million people were killed in the colonies, Europe was industrialized, precapitalist states were transformed into nation states, racism became an overarching ideology and close links between capital, trade and the state apparatus were formed. These consequences persist, even though Europe no longer dominates the world. All of the poor countries today are former colonies, while the former colonial rulers belong to the group of rich countries. Only a few of the former colonies managed to rise to the status of a rich country. Colonialism forms the most relevant socioculture of the contemporary world and explains many of its inequalities on a global scale. I will return to this point further down.

\section{Trade and finance}

Colonialism was closely linked to finance and trade. While in Venice trade between Asia and Europe was the focus, robbery formed the nucleus of English colonialism. Both were capitalist activities - which, following Weber, consists in the investment of capital with the expectation of a profit. Trade is usually financed by capitalists, often on the basis of a credit extended by a financial institution to a trader. This was 
the usual pattern in Venice of 1200 just as in England of 1600. The main agents of long-distance trade and colonialism were corporations that were financed by banks and controlled by aristocracies.

This capitalist business was based on an important (re-)invention, namely the bill of exchange, around 1200 (Braudel, 1979). The bill of exchange is a piece of paper, for which a debtor receives money and by which he promises to pay back the equivalent sum at a later point in time. Usually, the creditor receives an interest payment in addition to this sum. In the sixteenth century, the bill of exchange was developed to the degree that it could be sold on to a third party along with the right to payment plus interest - which is the root of the bank note as well as of the government bond.

In the end, the creditor receives his investment and a profit, while the debtor pays the original sum and an interest rate. The debtor loses money, unless he uses the credit to invest in a business that generates a higher profit than the interest rate. This is the goal that capitalist trade pursues. Capitalist traders usually need a credit in order to buy goods, which they later sell at a higher price. This has nothing to do with private credit or mortgage, where a consumer spends the entire borrowed sum on goods of consumption, which he or she uses, and has to generate an income by labor in order to pay back the credit plus interest. The trader, in contrast, buys in order to sell at a higher price.

While European long-distance trade was increasingly conducted by colonial corporations, finance was increasingly in the hands of banks. The princes and noblemen in the Italian city-states were often bankers at the same time, especially after the thirteenth century. Probably the most famous example is the Medici family that dominated Florence from around 1400, owned the largest bank of the city and had several popes in the sixteenth century. Finance was the most important business in Northern Italy of the Renaissance. It was closely linked to trade but not so much to production.

Marxists and classical economists usually argue that money is only a symbol for "real" values, especially manufactured goods. This is misleading. Finance capital is a means of power. It can be a value in itself, it does not have to represent anything else. In addition, it is backed by the state, which is the owner of its entire territory, its infrastructure and, to some degree, its population. The state backs the capitalist's claim to power by guaranteeing the "value" of a piece of paper. The power consists in the right to use labor, nature, resources and capital itself. Financial capital has been an essential component of capitalism, no matter whether you date its beginning to the thirteenth century in Italy, the sixteenth century in Western Europe or the eighteenth century in Britain. 


\section{Expropriation}

There are reasons to date the beginnings of modern Western capitalism, which I will refer to as institutionalized capitalism, to Britain in the seventeenth century. Three developments were significant to construct capitalism as an institution that comprises all sectors of society. Firstly, the population was disowned. Secondly, the United Kingdom was transformed into a nation state. Thirdly, national debt was privatized by a national bank. In connection with colonialism, finance capital and the exploitation of resources that were already present in Italy, these are the most important historical determinants of institutionalized capitalism.

The Ottoman conquest of Constantinople in 1453 shifted European trade routes from the Mediterranean to the Atlantic. England achieved a dominant status in the Atlantic after destroying the Spanish Armada in 1588. At this time, England had achieved a level of capital concentration that was unknown elsewhere. Its roots lay in the wish of King Henry VIII to divorce from his wife, which was not possible under the statutes of the Catholic Church. In order to legalize divorce, he declared the Anglican Church to be independent of the Catholic Church. Thereby, he took control of the Church's possessions. He sold much of the real estate and gave some land to his entourage (Tawney, 1966).

Only few people in England had the means to buy land, which resulted in an extreme concentration of real estate. This was used for commercial agricultural production leading to an increase in wealth concentration. This development continued, as buyouts characterized the seventeenth century and the conversion of community land into private property happened in the eighteenth century (Gray 1998). Noble families, including the royal household, continue to hold much of the real estate in Great Britain to this day (Irvin, 2008: 13).

The privatization of real estate entailed that people could no longer practice subsistence farming but had to seek employment and to buy their means of subsistence. However, there was no work beyond feudal serfdom in the sixteenth century. Pauperization and emigration were the consequences, epitomized by the arrival of the Mayflower in North America in 1620. The flow of people into the colonies continued over the centuries and only stopped after the end of industrialization. Industry itself could not absorb all the rural-urban migrants, not even in its heyday of the nineteenth century.

Expropriation forces everyone who has no capital to seek wage-labor. In all other forms of society, it was, in principle, possible to seek a piece of land and live off 
its produce. This might have been practically impossible for slaves and servants but whoever managed to leave patrimonial relationships was able to find plenty of unoccupied land without owner. Today, this option no longer exists. Basically the entire surface of the planet is private property. All of us, who own no capital in the strict sense, are (potential) laborers and consumers.

\section{The nation state}

Until the end of the Thirty Years' War in 1648, European states were entities owned and run by monarchs and princes. The entire state apparatus of Queen Elizabeth comprised a few hundred persons and was more or less identical with the court (Suerbaum, 1989: 132). The monarch ruled over a population and exploited it to his or her own benefit. After the Thirty Years' War, much of Europe was divided into territories and rule became increasingly impersonal, legalized and bureaucratic. The feudal state was slowly transformed into a nation state.

The nation state differs from the feudal state in several regards. First, it is no longer a private matter of the ruler but the ruler represents the population. Second, the nation state has a legal framework. Third, it has a territorial border. Fourth, the population is increasingly interpreted in a nationalistic way - with a supposedly uniform history, culture and language. In reality, there were no such states at the end of the Thirty Years' War. It took centuries to complete this transformation. The United Kingdom achieved it toward the end of the seventeenth century, some former colonies only toward the end of the twentieth century. It entailed integration, pacification and control of the population on the inside and protection against the outside (Foucault, 1977). It also created a uniform national market on the inside and pursuit of profits on the outside.

The English nation state emerged out of a long civil war. In the end, nobility, royal household and new capitalists reached a compromise, which characterizes the state to this day. These three groups monopolize wealth and have monopolized political power until quite recently (and continue to do so to a significant degree, since monarch and House of Lords still yield a lot of power and the rich dominate the lower house). The three groups had already been cooperating in the colonial enterprise for a century and the nation state continued to be largely a colonial enterprise well into the twentieth century.

Institutionalized capitalism was a global project from the start. Trade in Venice and Genova as well as Portugal and Spain had a global horizon. But England (viz. the United Kingdom and Great Britain) became a nation state, which integrated the 
entire population into the project of capitalism and global expansion instead of limiting it to a few companies. All of these states were in a permanent state of war around the world as long as they aimed at capitalist expansion abroad.

\section{Sovereign debt}

In order to understand the capitalist configuration in the European nation state as opposed to earlier states, we have to turn to the specific relation between capital and state. In the Italian states, there was a close connection between ruler and finance. Portugal and Spain financed their expansion via exploitation of the colonies - by and for the sake of the monarchs. England developed a system of credit finance, in which capitalists invest in sovereign debt in order to make a profit. This entails a certain degree of leverage by the creditors over the state. Finance capital controls trade via credit and the state via sovereign debt (Henwood, 1998: 22). The distinguishing characteristic of sovereign debt is that it is rarely paid back but causes a constant flow of interest payment - by the state to the capitalists.

Because of the European wars, colonialism and the civil war, the English monarch accumulated an enormous level of debt in the seventeenth century. In 1694, after the end of the civil war, the Bank of England was created as a corporation. The bank converted the debt of the state into government bonds and sold them. The receipts were "Bank of England Notes", the first banknotes. The owners of these banknotes received interest payments over a fixed period of time. After this, the state was supposed to purchase them at their nominal value. Thereby, the owner made a profit, which could amount to double of the original investment. However, the state rarely repaid its debt but rather financed the purchase of the government bond with another bond which entailed more flow of interest to the owners of capital.

In the eighteenth century, sovereign debt became the foundation of finance capital (Phillips, 2002: 214). The Rothschilds, very likely the world's richest family up to this day, are probably the most famous example for the power and significance of sovereign debt in Europe. But the development in the USA may be more relevant. Many of the richest families of the US became wealthy on the basis of sovereign debt, which was organized by influential politicians of British origin, such as Robert Morris, Alexander Hamilton and William Duer (Phillips, 2002: 214).

Most important is the power that the ownership of sovereign debt entails. While the feudal monarch may have been indebted, he or she was still the supreme ruler. The Italian prince was dependent on finance, but he was often a banker himself. 
The nation state, however, becomes an entity that has no autonomy from financial capital, as long as it is indebted. The worst thing that could happen from the perspective of capital is that a state repays its entire debt. The best thing is repayment by means of new government bonds - and this is what usually happens. Basically all nation states today are heavily indebted. Thereby, they are entirely dependent on finance capital and constantly move money to it. I will return to this further down.

Sovereign debt continues to be highly significant. It constitutes a continuous flow of interest to the owners of capital. Interest is paid by the state, which means largely by tax payers. The state would have the power to simply print the money it needs or to erase its debt. After wars and revolutions, this has been suggested and sometimes carried out. But usually, members of government thwart this option, since they either own government bonds themselves or act in the name of capital owners. Alexander Hamilton is a good case in point (Phillips, 2002: 16).

\section{Technology and industry}

The colonialist nation state spread capitalism across the world. However, feudal conditions continued to persist in many European societies, while subsistence farming and patrimonialism prevailed in many colonies, especially in Asia. Much of the world population lived outside of capitalist structures, even in England. Capitalists made profits through exploitation of resources, slavery, trade and finance. Only industrialization created a demand for labor. Since free laborers were cheaper than slaves in the long run, as they carry all risks, take care of their subsistence and can be easily replaced, slavery gave way to wage-labor.

Schoolbooks like to link capitalism and industrialization. The industrial revolution, however, only began in the eighteenth century, especially with the invention of the cotton gin in the 1760s and the (re-)invention of the steam engine in 1784. European industry did not play a major economic role before the nineteenth century. In 1820, Asia still had a share of 59 percent in global production, more than Europe, the US and the rest of the world combined (Polanyi Levitt, 2013: 158). Until this time, production in Europe was mainly organized in guilds. Technological innovation was important but economic growth resulted mostly from an increase in labor use (Pomeranz, 2000: 91).

The key development of industrialization was the scientifically planned mass production, which first emerged in Great Britain after the late eighteenth century. In this period, the classical works of economics were written by Adam Smith, David Ri- 
cardo and Karl Marx. They considered industry to be the core of capitalism and natural science the means to understand and administer it. However, industry formed the core of capitalism for not even two centuries. Today, industrial production contributes not even twenty percent to the GDP of the US - less than in Nepal. This also means that the exploitation of wage-labor is merely one aspect of capitalism. And science plays an inferior role in most other aspects of capitalism.

Industry requires large-scale investments and large markets. Both were partly delivered by the British colonies. Invested capital was generated by the colonial profits, proceeds from real estate and financial speculation. The manufactured goods were sold partly in the colonies. As is well known, the textile industry was the pioneer of British industrialization. India's textile production was superior to the British but it was prohibited by the colonial administration (Panikkar, 1955: 51). On this basis, all Indians had to buy textiles manufactured by British textile factories. India continues to suffer from this destruction of its industrial base and its traditions.

Industrial production was the core of capitalism only while profit rates were higher than in other spheres of the economy. This was the case only under colonial conditions. The colonial powers were able to import their raw materials at a very low cost from the colonies, process them in their factories and sell the products at high prices. With the end of colonialism and the shift of production to low-cost countries, profitability of the industrial sector decreased in Western countries. Capital returned to trade and finance.

The profitability of industrial production is based on the (almost) free acquisition of raw materials - from water and oil to timber and precious metals. The productivity of scientific manufacturing contributes far less to capitalist profits than the exploitation of nature. All societies live off nature but only capitalism developed the ability to destroy the planet. Adam Smith already described the systematic destruction of nature for the sake of capitalist profit in 1776 (Smith, 2007: 105-113).

Industrial production is unthinkable without the exploitation of nature. At the same time, most means of subsistence - water, shelter, food - are accessible today only via the capitalist system. Only (polluted) air is still free. The exploitation of nature in capitalism is systematic (Moore, 2015). Whereas earlier societies left significant parts of nature untouched, capitalism transforms an increasing number of things into goods in order to generate a profit. We all know that this process is about to destroy the foundations of life. It is important to note that it is not a component of "human nature". Kleenex does not clearcut old forests nor does Shell drill for oil in order for humanity to survive. They do this in order to make a profit. 


\section{Capital and market}

Textbooks tell us that the economy in a capitalist society is organized as a market and comprises all productive activities. However, the majority of productive and necessary activities takes place outside the "market". We help our neighbor build a shed, a friend move to a new place, our daughter with her homework and the aunt organize a party. These activities are productive and could be measured in money. In addition, we have to consider reproductive activities, such as child-rearing and housework. All of these activities combined probably comprise the majority of economic activity - but they are not organized as a "market". I would call this the social economy.

The term "market", however, is misleading as well. The baker next door may use flour of bad quality and charge excessive prices but he only uses his income to pay for his own livelihood. With your shopping you basically pay for his shopping and both of you consume the acquired goods to stay alive. You could go shopping elsewhere. If the baker's products are too expensive or too terrible, you probably would. This is a market. Several suppliers compete via quality and price for customers. If the market is organized by the state on a national level, we may speak of a market economy.

Capitalism has nothing to do with the market, which Fernand Braudel has shown convincingly (Braudel, 1985). Capitalism is not about competition among equals who try to secure their livelihoods but about profit and accumulation. Only a section of the economy is organized as capitalism. This section first comprised finance and trade and was then extended to the exploitation of European colonies and finally penetrated the entire society, both in Europe and in the colonies. The apparatus of the nation state mainly served the purpose of organizing and protecting this sphere of the economy. The market in the strict sense, as introduced in the preceding paragraph, does not require any organization, since demand and supply regulate everything via quality and price.

The capitalist "market", in contrast, is organized in such a way that capitalists' profits are secured. The capitalist section of the economy has always consisted of oligopolies or even monopolies. Corporations of the past, such as the colonial companies or the American railway trusts, had state-backed monopolies, at least for a certain region. If any competition emerged, it was done away with by mergers or destruction of the competitor. Today, any sector of the capitalist economy is dominated by a few corporations - which tend to own each other. The appearance of competition is maintained by anti-trust legislation and the existence of several 
brands but in reality, all corporations are owned by the same group of capitalists. I will expand on this further down.

The different segments of the economy - social economy, market, market economy and capitalism - do not exist independently of each other but capitalism seeks to incorporate those fields that could generate a profit. It thereby changes the other segments. At the same time, elements of the market and the social economy persist within capitalism. For example, any person who is active in the field of capitalism also makes presents or exchanges goods and services. Without these activities, capitalism could not function. If the entire economy were geared only to profit-making, the majority of vital activities - from birth and education to friendship and public services - would disappear. Capitalism can be interpreted as a parasite that lives off a host, which is society, including the social economy.

Textbooks claim to describe capitalism but actually talk about the market. In the public language of marketing, politics and media, there is no difference between the baker next door and Rockefeller. Liberal economists from Adam Smith to Milton Friedman always illustrate the functioning of capitalism with regard to an exchange between two Robinson Crusoes or at best a farmers' market. These have nothing to do with capitalism. Such representations are intentionally misleading in order to legitimize capitalism.

\section{Political legitimation}

As a consequence of the Thirty Years' War and the civil war, the United Kingdom installed a parliament. However, only a small fraction of the population was represented in it, namely the nobility in the upper house and the bourgeoisie in the lower house. Well into the twentieth century, government and leading bureaucrats were recruited only from these two groups. It was a democracy of capital owners (Polanyi Levitt, 2013: 147). This changed only with the social reforms by the Labour Party after the Second World War.

Textbooks tell us that the French and American revolutions made democracy a reality and that the West became democratic. However, many European states witnessed democratic revolutions only in the twentieth century or not at all. And until the twentieth century, the majority of the population was excluded from democracy, even in France and the US. Slaves and workers gained citizen rights in the late nineteenth century, women and people from the colonies in the twentieth. Some groups, such as foreigners and convicts, are denied citizen rights up to this day in many countries. Democracy was introduced step by step over centuries. The for- 
merly underprivileged groups remain underprivileged because their lack of means and respect was never compensated for.

Today, most nation states call themselves democracies: Great Britain with a monarch and an aristocracy privileged by the constitution, Sweden with a strong social system and a monarch (and the highest wealth inequality in the world), Switzerland with elements of a direct democracy and China with a communist one-party rule. None of these countries has made equality a reality. They differ significantly from one another but they have in common that capitalists are privileged. The differences result from history and political struggles. Some countries have abolished many privileges of the nobility and some have even limited the privileges of capital. The structures of domination, however, with a tiny privileged group dominating the rest of society persist everywhere.

The degree of inequality in capitalist societies is evident to any observer. At the same time, democracy proclaims the ideal of equality. In any democracy, there is a tension between the concentration of capital and the ideal of equality. It plays out as a conflict between state and economy (or "market"). In principle, the population has the option to change the status quo and to achieve more equality via the state. Capitalists try to prevent this and have many powers to do so but the possibility of creating more equality exists and is sometimes realized.

That this rarely happens is partly due to the symbolic universe of capitalism and the way inequality is legitimized. Inequality in capitalism is supposed to be the result of competition between free and equal individuals - in contrast to other forms of organized states, which were openly unequal. The meritocratic myth was shaped by mainstream social science since the seventeenth century, especially by liberal traditions. Even though it clearly contradicts everything we experience every day, all of us believe at least to some degree in the meritocratic myth: we are all equal, all opportunities are open to everyone of us, inequality results from competition on a level playing field, and whoever lives in misery has to take at least some of the blame.

Liberalism and the meritocratic myth can be traced back to Thomas Hobbes who published his main work, Leviathan (Hobbes, 1986), in the midst of the English civil war in 1651. Hobbes applied Galileo's mechanics to society and interpreted human beings as identical atoms. Just like Galileo explained the physical world on the basis of one single defining characteristic of the atom, namely movement, Hobbes explained the social world on the basis of the defining characteristic of the human, namely survival or self-interest. Since self-interested beings would kill each other 
in an endless competition, Hobbes called for a regulating force: each individual transfers some of its powers to the sovereign (or state) that limits self-interested action and guarantees a peaceful competition. Hobbes suggested that a monarch be the best incorporation of the sovereign but a century later, Rousseau replaced the monarch by the idea of a democracy, which was then partly realized by the American and French revolutions.

Adam Smith's economics is basically an application of Hobbes' socio-political science to the economy. In the Wealth of Nations, published in the same year as the American Declaration of Independence (1776), Smith explains that the market guarantees a maximum of productivity, quality and price efficiency, if it is an unfettered competition between legally free and equal individuals (Smith, 2007). The same should be true for the world market of nation states. Nations and individuals should pursue their self-interest and, in the course, specialize on what they do best. Thereby, they would acquire relative advantages. Smith suggests a similar role for the state as Hobbes: to regulate markets in such a way that a free and equal competition is possible.

Just like Hobbes, Smith ignores the inequalities between individuals (and nations) before any competition. He takes for granted that there are capitalists and laborers and that capitalists should get the profits and laborers a wage to secure their subsistence (Smith, 2007: 7). He has no problem admitting that there are classes in society and that people are born into and die in their class. Since the advent of democracy, this is no longer acknowledged. Everyone is supposed to be equal - in spite of the existence of slavery, exclusion of women and no voting rights for the poor. Today, with full suffrage for (almost) everyone and full economic rights for all, this seems to be a problem of the past.

\section{Emergence of classes}

Inequality is not a result of competition, it is a starting condition. All the inequalities mentioned in the previous paragraph persist because they have never been compensated for. Women were given the right to vote - but at that point, men had already captured all leading positions in society and all capital. Slaves were freed - but they had no education, no money, no connections, no respect, no access to jobs and markets. The poor were given the right to participate in the market - but they had no capital. The formerly excluded groups were able to achieve minimum rights through long struggles but they never received even a small fraction of the privileges of the formerly included groups. They were integrated as subalterns into the "democracy". This is the basis of our invisible inequality. 
Until the twentieth century, no democracy included the entirety of its population, not even its majority. And there was never a complete break with the past. Monarchy and nobility were never entirely abolished. In fact, many nation states around the world still have a monarch and many a nobility, including Great Britain, where the royal household, nobility and capitalists formed a new dominant class after the civil war. This happened in most European and American as well as in some African states. The old ruling groups merged with the new capitalists and excluded more or less all others from the new "democratic" state. In many Asian and African states, a more inclusive democracy was installed right with independence but earlier hierarchies were not done away with either. The old dominant groups and elites remained on top.

Three general types of states resulted from the transition to capitalist democracy (Jodhka et alii, 2017: 14). The nation states with a long capitalist and democratic past in Europe have established stable class structures. Neither the precapitalist structures nor contemporary class structures are openly visible any more. In contrast, the slave-holding settler colonies of America experienced independence around two centuries ago but the former slaves received full citizenship only in the twentieth century. The legacy of slavery is still openly visible. This is partly true for the relation between settlers and indigenous populations in Oceania and Southern Africa as well. The third type includes most nation states of Africa and Asia, which received their territorial borders and independence only a few decades ago. Precapitalist structures and inequalities remain clearly visible.

Some nation states do not fit any of the types, since they were never fully integrated into the colonial system, such as China, Ethiopia and Thailand, or since they have a peculiar history. But inequality in all contemporary nation states is only intelligible as a transformation of precapitalist hierarchies - or sociocultures. The formerly underprivileged groups remain underprivileged and the formerly dominant groups mostly retain their dominant position. In capitalist society, these hierarchies slowly develop into social classes.

\section{Economic classes}

Marx' division of society into capitalists and laborers is a gross simplification of the diversity of social structures that exist around the world. Each nation state has its particular inequalities that are transformations of precapitalist hierarchies and therefore a unique structure of social classes. However, Marx is entirely correct when speaking about economic classes. Only a tiny group of people, around 0.05 
percent of the world population, owns capital in Weber's sense: wealth that is invested with the expectation of a profit. The rest has to labor and depends entirely on the capitalists. Marx (1985: 523) explained that the laborer only has a life if he (or she) finds a capital that employs him (or her). In an economic sense, capitalist society consists only of capital and labor.

In order to fully understand this, we have to clearly define capital. Capital is not wealth or property or income or money. Only an investment with the expectation of a profit is capital. Any income can be used for consumption or saved. If it is consumed, it is gone. If it is saved, it can be used for future consumption. When money is saved and invested with the expectation of a profit, it can become capital. Whoever owns a few company shares or a life-insurance policy cannot be called a capitalist because he or she does not have any influence on his or her own investment but is entirely dependent on company policies. This is reflected in profit rates. While the regular person is happy if his or her savings increase at all, a capitalist aims at a profit rate of at least several percent. Furthermore, capitalists finance their livelihood entirely from profits, while savings are usually consumed at some point.

Capitalists lend capital to the rest of the population for a fee. An industrialist, who has to take up a credit, uses the capital for his or her own profit but still has to pay a fee. Whoever uses real estate, has to pay a rent. Whoever uses money, has to pay an interest rate. And everybody has to buy the means of consumption from the capitalists. Thereby, almost all investment flows back to the capitalists - except savings that is invested for a profit, which is not used up by the investor. One might argue that the state apparatus controls up to half of the GDP. But what happens with that money? The state uses it for social transfers, which are converted into means of consumption, for infrastructure, which is constructed by capitalists, for interest payments on sovereign debt, for weapons and for civil servants, who spend their salaries on means of consumption. Only a segment of the state budget, e.g. for education, does not end up fully in the pockets of the capitalists.

Of course, anyone in a democratic society is free to invest capital. Whoever does not own any money, can get a credit. But few people do this, since risk is high and economic processes are largely unknown. In fact, it is highly unlikely that a complete outsider starts a successful business. Capitalists, in contrast, usually inherit not only the invested capital but also the knowledge and the contacts. They do not have to acquire or borrow any money and can live off the profits. The remainder of the population has to serve the capitalists in order to acquire the means of survival. However, there is no logical reason for the capitalists to pay any particular level of salaries, it is the result of centuries of struggle. 
The economic class of capitalists comprises not much more than 0.05 percent of the world population. In 2015, around 33.7 million individuals in the world (or about half a percent) were millionaires in US Dollars (Stierli et alii, 2015: 26). With a wealth of one million dollars, you may be a capitalist in a poor country but in the global North, where most of the millionaires reside, a million buys you two houses, three cars and maybe a boat. All of these are consumer goods, not capital investments. You may be able to buy a life-insurance policy and a few stock shares but these are controlled by others. The majority of millionaires does not qualify as capitalists. It is safe to draw the statistical dividing line between capitalists and individuals who own some wealth at around five million US Dollars in the global North and at around one million US Dollars in the poorer countries of the global South. This leaves us with around 0.07 percent of the world population as potential capitalists (Stierli et alii, 2015: 27).

The entire remainder of the world population has to labor or receive transfers in order to make a living. Around 14 percent can be classified as an economic middle class, while 71 percent of the world population owns wealth of less than 10.000 US Dollars (Stierli et alii, 2015: 30). The distance between the laboring class and the capitalists can be visualized by equating one million US dollars with one centimeter. 99.5 percent of the world population would be placed within that one centimeter. The average capitalist would be nineteen centimeters away, while the billionaires would be more than 1.000 centimeters (ten meters) and up to a hundred meters beyond. And the distance is increasing by the day. It has never been as large as today (Phillips, 2002: 110).

\section{Finance capitalism}

Above, I claimed that capitalism has always been and still is a matter of oligopolies and monopolies, that it has nothing to do with a market. This was visible with the colonial companies and the great American trusts. The concentration of capital is even more extreme today but it is difficult to see. The capitalist economy is run by a network of corporations, which are owned by a few transnational corporations (TNCs), whose owners are hidden behind a maze of company shares, shell companies, holding societies and foundations.

An important study by Stefania Vitali, James B. Glattfelder, and Stefano Battiston (2011) analyzed the ownership structure of TNCs worldwide. Vitali et alii selected the most important TNCS from the Orbis database 2007, which comprised thirty million companies. They found that 15,491 TNCs have multiple ties to each other. 147 TNCs hold forty percent of control of all TNCs and almost fully control one an- 
other (Vitali et alii, 2011: 6). Three quarters of these TNCs are financial institutions that hold shares of up to 5,000 other TNCs (Vitali et alii, 2011: 20). It is safe to say that the network of these 147 TNCs forms the core of the capitalist economy.

We have to consider that the 200 largest TNCs were responsible of 28.3 percent of global GDP in 2000 (Anderson \& Cavanagh, 2000). Since the state is responsible for up to half of the GDP in some nation states, we can estimate that the network of the most powerful 147 TNCs controls up to fifty percent of the global GDP beyond the state.

Each TNC holds shares in other TNCs. Especially financial corporations have diversified portfolios with shares of less than three percent in a particular company. Thereby, each of the powerful TNCs owns a small percentage of every other TNC. Company shares are increasingly owned by financial institutions, especially investment funds. BlackRock is the biggest and most notorious of them. Banks like Merrill Lynch and Barclays, in turn, hold the majority of BlackRock shares. But who actually owns the corporations' capital then? We have to answer the question by studying who invests via these funds. BlackRock administers up to seven percent of global financial wealth and requires a minimum investment of one million US dollars (Dowbor 2017: 106). These are the people who, in the last instance, hold the capital of the TNCs. Only the world's capitalists are potential - and actual customers.

Today's capitalists no longer own particular companies, which they run on a daily basis. Those who build companies from scratch usually sell at least part of them after a few years. Capital today is invested via financial institutions that are only interested in the profit rate. Each TNC has to generate a certain minimum profit, often up to ten percent, in order to attract capital investors. The TNC's financial department receives the profit aim from the financial investors and passes down the aim to all sub-companies and departments. Quality and price of the products have become basically irrelevant. How the profit is generated, does not play any role.

The economic class of capitalists increasingly acts as a block of investors, mediated by financial institutions. These might invest the money in productive companies but also in speculation, extraction of raw materials, real estate and other processes that are, in classical economics, not considered productive. In fact, most of the capital does not lead to any economic growth or social wellbeing (Stiglitz 2012: 39). Capitalism never pursued this goal. It is more about generating profits for privileged self-interested individuals. 


\section{Social classes}

However, capitalism is not about money. It is about capital. From this perspective, there are only two classes, namely capitalists and laborers (or non-capitalists), as Marx has argued. But capital is only a means and capitalist society, in the last instance, is not even about capital but about domination. Therefore, the division of society into two economic classes is oversimplifying and misleading. Many members of the Rockefeller family are not active as capitalists and some may not even have any significant wealth or income. They do not belong to the economic class of capitalists. But they are still members of the upper social class. In contrast, a newly rich may be a capitalist but will not have access to the upper social class, since he or she lacks the contacts, the manners, the knowledge, the family name and the respect. A successful football player may have more money than many members of the upper social class but he will not become a member of the upper class.

Social class is more fundamental than economic class, since domination is more fundamental than capital. A social class is, among other things (see the section on definitions), defined by a common tradition, a common culture, almost like an ethnic community. The culture is embodied in the habitus (Bourdieu, 1984). Habitus refers to the socially relevant patterns of behavior that are acquired in the life course, mostly in childhood. Patterns of behavior are usually acquired in a stable social environment and adapted to it. This is often the parental sphere of life; most of us learn many important forms of behavior from our parents. Therefore, we have a lot in common with people in the social environment of our childhood, typically our parents and siblings. The earlier a pattern is acquired, the more stable it tends to be. Examples would be the mastery of a musical instrument or the ability to play golf, which are usually acquired in childhood and in a typical social environment. Since the environment does not change significantly all the time, patterns are somewhat coherent and stable over time.

A social class is partly defined by a habitus. Its members have similar, albeit not identical, patterns of behavior. It is also determined by other factors, such as economic capital, labor, education, cultural goods, abilities, manners and language. All these factors combine and form a typical combination but any one factor can be untypical for any member of the class. A certain member of the Rockefeller family may lack university education, another may have no personal wealth and a third may be married to a middle-class person - but no member of the family will have all of these characteristics. The successful football player may be rich but he has no university education and no friends from the upper class - unless he belonged to the upper class before becoming a football player. 
Class culture is reproduced from one generation to the next, since habitus and institutions cannot be altered at will - they rather form the basis of any alteration. It comprises all socially relevant patterns of action. Of course, social class also comprises access to economic capital or to labor (or the lack thereof) but habitus and social networks are at least equally important. Social class is defined by all socially relevant factors that distinguish the classes hierarchically. We can define social class as a socio-cultural collective that passes on key elements of habitus and resources from one generation to the next and distinguishes itself actively and passively from other classes (Jodhka et alii, 2017: 20).

Social class can be operationalized by looking at the limits of social mobility (Jodhka et alii, 2017: 20). In order to determine social mobility, we have to take the entire life course and the entire family into account. One individual may seem to have been socially mobile for a certain period of time - but this is rarely the case over the entire lifetime and virtually inexistent for an entire family. A lot of mobility exists within a social class but the boundaries of a class are rarely crossed. A university student is usually poor but comes (at least) from a middle-class family and usually gets (at least) a middle-class job. A poor winner of the lottery may become rich but usually loses all of his money before the end of his life. In principle, upward mobility is possible in a capitalist society, even if it is rare. However, social mobility also existed in precapitalist societies. And the patterns are similar. Access to the upper class mostly happens through personal networks, especially marriage.

Money and capital are some of the privileges that come with membership in a social class. Capital is the most important instrument of preserving hierarchy and domination in a capitalist society but it is only one privilege among many. Social class is defined by a combination of privileges, all of which amount to domination. Domination is the power to influence society and impose one's will. The hierarchy of social classes is a structure of domination.

The upper social class is the dominant class, since it occupies the dominant position and is capable of domination. The rest of the population is told that capitalist society is about wealth. This makes the structure of domination invisible and forms an incentive for people to labor and consume. The acquired wealth mostly ends up in the capitalists' pockets. Most capitalists are members of the dominant class, since they inherit economic capital, the relevant social networks and family ties, knowledge about business and a fitting habitus. We are made believe that ownership of capital results from competition but this competition starts with the capitalists already having capital. The competition for economic capital is basically limited to the dominant class. 
The basic structure of a capitalist society consists in a hierarchy of social classes. All capitalist nation states have a dominant class and a marginalized class, which is excluded from access to valued functions in society, e.g. labor. The number and structure of middle classes varies depending on the history of the nation state as well as the timing and nature of the capitalist transformation. The structure of social classes is rooted in precapitalist hierarchies or sociocultures, which partly persist for generations after the emergence of capitalism and partly shape the social classes.

\section{Inequality and global capitalism}

The competition for capital and domination has been mediated by the nation state and has thereby partly been confined to it. The nation state is at once the arena for the competition between national capitalists and the support structure for transnational expansion. The emergence of institutionalized capitalism was tied to colonialism and, as a consequence, was global from the start. Marxists like Rosa Luxemburg (1921: 107) have argued that the generation of surplus entails global expansion as a law. This is misleading since no natural law forces human beings to a certain social behavior. At the same time, neither capitalists nor members of the dominant class form a homogeneous group with one common strategy. They rather compete with each other for a better relative position. This is the case on the global level as well as on the national level and often even within the family.

Furthermore, the interests of capitalists diverge from those of dominant classes and nation states. States are led by politicians who are interested in their careers and a strong position of the state. Capitalists are interested in their personal profit. Dominant classes wish to preserve their social position. For capitalists residing in a globally weak state, a strategy strengthening the state could be negative, for example if they profit from development aid, the exploitation of resources or corruption. And aggressive profit-seeking could be negative for the dominant class, since it leads to instability and rebellion.

Only in the globally dominant state, all of these interests can converge, since they all aim at global domination. It is evident that the US replaced Great Britain as the globally dominant state in the early twentieth century. Only the American dominant class profits from this position. More than 15 percent of the American population live below the line of poverty (Stiglitz, 2012), and the misery of the British working class at the height of British imperial power in the nineteenth century has been described in much detail (e.g. Marx, 1985: 477-490). The lower classes of Great Britain and the US also had to fight the wars of global expansion and pay with their lives to the benefit of the upper classes. Any of the capitalist great powers 
- from Venice to Florence to Spain to Britain to the US - has been in a constant sate of war.

From this, we might want to conclude that the dominant class of the US dominates the world via the US government. This is partly the case, since the interests of the dominant class, the government and the capitalists largely converge - in global domination and total globalization. However, this hypothesis grossly underestimates the competition within the dominant class as well as the differing ideological and moral ideas of their members. And a conspiracy theory underestimates the size of the class, which makes coordinated action virtually impossible. Finally, while Great Britain had to compete with Holland, France, Germany and other powers, the US has to compete with Russia, China and increasingly India. The dominant class of the dominant nation state is not the global ruling class.

All other states and their dominant classes are more or less dependent. Any dominant class is largely confined in its power to the respective nation state but more so in the dominated states than in the dominant ones. At the same time, capitalists have become global. Increasingly, there is only one global capitalist class in economic terms, as described above. Capitalists tend toward globalism, while dominant social classes tend toward nationalism - and this conflict often takes place within one and the same individual.

Since the unfolding of capitalist colonialism, the dominant class of the dominant nation state instrumentalized the state apparatus to improve its global position with the aim of global domination. This happened via the accumulation of capital. The colonial world was dominated by the colonial powers, especially Great Britain, while the colonies were clearly dominated. This was legitimized by racism: the dominant were supposed to be biologically or culturally superior. However, each nation state developed its internal hierarchy in the wake of colonialism.

The colonial hierarchy was increasingly transformed into a hierarchy of social classes. In the colonial center, the feudal socioculture slowly evolved into a class structure, while the colonial socioculture in most of the rest of the world persisted in a slightly transformed shape after independence, especially in the Americas. The relationship between the former colonial center and the rest remained just as unequal as the relationship between the former colonial elites and the formerly colonized populations. Colonialism gave way to dependency and racism to modernization theory.

After the end of the Cold War, an integrated global capitalism began to develop. There is a tendency toward one single capitalist class and a tendency toward a 
single economic system. We are also seeing organizations of global government emerging, such as the United Nations, the World Bank, the International Monetary Fund or the World Trade Organization. The structure of the global system resembles the colonial world, since the descendants of the colonial elites form the upper classes around the globe and the colonial center mostly remains the center today. However, racism and modernization theory have been supplanted by meritocracy, while the nation state continues to be the most important unit of social action and social hierarchy. Racism and modernization theory correspond to earlier sociocultures of the world: the colonial world into the twentieth century and the world of the Cold War until 1989. They shape the current structure and partly persist. But they slowly give way to global capitalist society.

The structure of each nation state can be explained by a combination of its history and its position in the global capitalist system. We have to interpret the internal structure as a transformation of sociocultures. The position in the global system is a transformation of the state's position in the colonial world and the order of the Cold War. Furthermore, the timing of the capitalist transformation and political measures as well as consequences of revolutions, war, disasters and other major events are important parameters in explaining the structures of inequality in detail. This goes beyond the scope of this paper (for more details, see Jodhka et alii, 2017).

\section{Conclusion}

It is important to understand that capitalism is not a system of natural laws but entirely shaped by human beings. It is equally relevant to interpret it as parasitic; it feeds off the social economy and the market, from which it has to be clearly distinguished. Most important, however, is to view capitalism as a dimension of domination. Capital is not an end in itself and the capitalist economy is only the surface of capitalist society. Any inequality is about domination, and in capitalism, domination is mediated by capital. As a corollary, social class is more fundamental than economic class. This is rendered invisible by the focus on money and wealth.

Capitalist society develops a hierarchy of social classes. Class position as well as class culture are passed on from one generation to the next. This is rendered invisible by the myth of meritocracy, which postulates that any inequality is result of a competition on a level playing field. In conjunction with the suggestion that competition is about money, the dominated 99.93 percent in capitalist societies are pushed to labor for the 0.07 percent - and to, metaphorically speaking, attack windmills. 


\section{References}

ANDERSON, Sarah; CAVANAGH, John. The Rise of Global Corporate Power. Global Policy Forum, 2000. <https://www.globalpolicy.org/component/content/article/221/47211.htmls.

BAIROCH, Paul. Economics and world history. Myths and paradoxes. New York: Harvester Wheatsheaf, 1993.

BOLTANSKI, LUC; CHIAPELLO, Eve. Le nouvel esprit du capitalisme. Paris: Gallimard, 1999.

BOSE, Sugata; JALAL, Ayesha. Modern South Asia. History, culture, political economy. London; New York: Routledge, 1998.

BOURDIEU, Pierre. Distinction. London: Routledge and Kegan Paul, 1984.

BRAUDEL, Fernand. La dynamique du capitalisme. Paris: Arthaud, 1985.

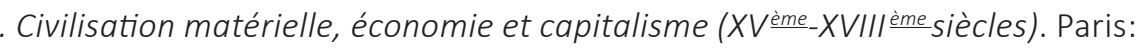
Armand Colin, 1979.

DOWBOR, Ladislau. A era do capital improdutivo. São Paulo: Autonomia Literária, 2017.

FOUCAULT, Michel. Discipline and punish. New York: Pantheon Books, 1977.

FRANK, André Gunder. ReOrient. Berkeley (CA): University of California Press, 1998.

GRAY, John. False dawn. The delusions of capitalism. New York: The New Press, 1998.

HENWOOD, Doug. Wall Street. How It works and for whom. London; New York: Verso, 1998.

HOBBES, Thomas. Leviathan. London: Penguin Books, 1986.

IRVIN, George. Super rich. The rise of inequality in Britain and the United States. Cambridge; Malden: Polity Press, 2008.

JODHKA, Surinder S.; REHBEIN, Boike; SOUZA, Jessé. Inequality in capitalist societies. London; New York: Routledge, 2017.

JONES, Eric L. Growth recurring. Economic change in world history. Oxford (UK): Clarendon Press, 1988. 
LUXEMBURG, Rosa. Die Akkumulation des Kapitals. Leipzig (DE): Frankes Verlag, 1921.

MARX, Karl. Philosophisch-Ökonomische Manuskripte. In: MARX-ENGELS-WERKE, Band 40. Berlin: Dietz Verlag, 1985.

MOORE, Jason W. Capitalism in the web of life. London: Verso, 2015.

NEDERVEEN PIETERSE, Jan. Empire and emancipation. New York: Praeger, 1989.

OSTERHAMMEL, Jürgen. Kolonialismus: Geschichte - Formen - Folgen. München (DE): Beck, 1995.

PANIKKAR, Kavalam Madhava. Asien und die Herrschaft des Westens. Zürich (CH): Steinberg-Verlag, 1955.

PHILLIPS, Kevin. Wealth and democracy. A political history of the American rich. New York: Broadway Books, 2002.

POLANYI, Karl. The great transformation. Boston (MA): Beacon Press, 1944.

POLANYI LEVITT, Kari. From the great transformation to the great financialization. London; New York: Zed Books, 2013.

POMERANZ, Kenneth. The great divergence. China, Europe, and the making of the modern world economy. Princeton (NJ): Princeton University Press, 2000.

SMITH, Adam. An enquiry into the nature and causes of the wealth of nations. Petersfield (UK): Harriman, 2007.

STIERLI, Markus; SHORROCKS, Anthony; DAVIES, Jim; LLUBERAS, Rodrigo; KOUTSOUKIS, Antonios. Global Wealth Report 2015. Zürich (CH): Crédit Suisse, 2015.

STIGLITZ, Joseph. The price of inequality. London: Allen Lane, 2012.

SUERBAUM, Ulrich. Das elisabethanische Zeitalter. Stuttgart (DE): Reclam, 1989.

TAWNEY, Richard H. Religion and the rise of capitalism. Harmondsworth (UK): Penguin Books, 1966.

THOMPSON, Edward P. The making of the English working class. Harmondsworth (UK): Penguin Books, 1963.

VITALI, Stefania; GLATTFELDER, James B.; BATTISTON, Stefano. The network of global corporate control. PLoS One, v. 6, p. 1-18, 2011. 
WEBER, Max. Gesammelte Aufsätze zur Religionssoziologie. v. I. Tübingen (DE): Mohr, 1986.

c) (i) (8) 